\title{
Forensic studies of phytoplankton ecology of two water bodies of Kurukshetra area of Haryana, State in India
}

\author{
Mukesh Kumar Thakar ${ }^{1 *}$, Deepali Luthra ${ }^{1}$ and Jasvirinder Singh Khattar ${ }^{2}$
}

\begin{abstract}
Background: In forensic investigations of death cases in which the body has been recovered from a water body, there is an urgent need to prove whether the death is due to drowning or not. Moreover, another important issue arises, whether a person was alive at the time of drowning (anti-mortem drowning) or he was thrown dead into the water body (post-mortem drowning) To answer these questions, phytoplankton species of forensic importance from two water bodies (Braham Sarovar and Prithus Pools) were analyzed to develop the Phytoplankton maps (Pmaps). The P-maps are basically a detailed list of categories of species which are common, site-specific, rare and seasonally occurring phytoplanktons along with their photomicrographs.

Methods: In the present study, water samples have been collected from Braham Sarovar and Prithus Pools situated at Kurukshetra area of Haryana state, India. The phytoplankton species present in both ponds were extracted by mild acid digestion $(5 \% \mathrm{HCl})$. The physico-chemical properties of these water bodies such as $\mathrm{pH}$, water temperature, total dissolved solids, electrical conductivity, hardness, alkalinity, calcium, sodium, potassium, and chloride ions have been recorded to establish a correlation with the distribution of phytoplankton using principal component analysis.

Results: Total 138 species of 59 genera of phytoplanktons belonging to Cyanophyceae, Chlorophyceae, Bacillariophyceae, Euglenophyceae and Dinophyceae have been observed. In Braham Sarovar, Cylindrospermum sp., Epithemia turgida, Eunotia rhomboidea, and Westella botryoides were the site-specific phytoplanktons whereas in Prithus pool, the site specific phytoplanktons were Leptolynbya granulifera, Arthospira jenerii, Cymbella cymbiformis, Frustulia vulgaris.
\end{abstract}

Conclusion: It is hoped that results/data obtained from the present study (P-maps) may go a long way in solving the mysteries related to the deaths due to drowning and can be usefully used as a reference data for determining the exact site of drowning.

Keywords: Phytoplankton, Forensic science, Diatoms, Aquatic bodies, Braham Sarovar, Prithus pool and P-maps, Principal component analysis, Diversity index, Drowning

\section{Background}

The recovery of a dead body from any water body does not always mean that the death is due to drowning. There can be other reasons also. In forensic cases, it is urgently required to investigate the real cause of death, whether it is due to drowning or not. In addition, few important questions arising in relation to it are:

Whether the drowning is anti-mortem or post-mortem?

\footnotetext{
* Correspondence: mukeshk38@gmail.com

'Department of Forensic Science, Punjabi University, Patiala, India

Full list of author information is available at the end of the article
}

The place where actual drowning took place?

To answer these questions, a diatom test has been considered to be the best marker of drowning but it confronted with many difficulties and hardships in terms of its reliability. It was shown by some of the workers that diatoms were also present in non-drowned victims due to postmortem invasion, autopsy contamination (Lunetta et al. 2013), inhalation of diatoms from the air (Otto 1961; Spitz et al. 1965), water and foodstuff (Yen and Jayaprakash 2007). However, the reliability of diatom test has been established by the majority of researchers by 
considering qualitative and quantitative criteria (Auer and Möttönen 1988; Ludes et al. 1999; Pollanen 1997; Singh et al. 2005, 2006a, 2006b; Thakar et al. 2011; Thakar and Singh 2009; Thakar and Singh 2010). In 1988, Auer and Mottonen suggested that minimum 20 number of diatom per microscope slide from lung samples is required to define the death due to drowning. Similarly Ludes et al. (1999) also suggested the limit of 20 diatoms per slide per $100 \mu \mathrm{L}$ pellet for lungs and 5 diatoms per slide per $100 \mu \mathrm{L}$ of a pellet sediment extracted from $2 \mathrm{~g}$ of tissue samples such as brain, kidney, liver and bone marrow. But under certain environmental conditions, diatoms may be scanty or absent in a particular water body, leading to a false negative diagnosis of drowning. Many studies on qualitative and quantitative assessment of diatoms during different seasons and at different time periods have reported lesser number or absent of diatom species in one season and their bloom in the other (Canini et al. 2013; Cumming and Smol 1993; Singh et al. 2010; Sushanth and Rajashekhar 2012). Pollanen (1997) also reported highly positive diatom test outcome in the body of drowned victims in the months in which diatom population in the water body was at a peak. This showed variations in the number of diatoms over a period of time in water bodies.

The forensic usefulness of phytoplankton came to light when Chardez and Lambert (1985) (cited in Lunette and Modell 2005) detected the presence of phytoplankton other than diatoms in the drowned bodies. They also found aquatic organisms belonging to division Chlorophyta, Dinoflagellates, invertebrates, protozoan ciliates in the blood of drowned victims. Later, Yoshimura et al. (1995) developed a method to recover phytoplankton from the tissue of drowned victims by using soluene-350. Various species of green algae (Staurastrum and members of Zygnemataceae) as well as diatoms (Navicula, Cymbella and Melosira) were detected in both putative water samples and tissue samples of drowned victims. In an another case a serious attempt has been made to link the suspects and victims to the crime scene by analyzing the sediment encrusted sneakers from both assailants and victims along with numerous species of diatoms and scaled Chrysophytes (planktonic algae) from the sneakers as well as reference samples of pond sediment (Siver et al. 1994).

Further in Díaz-Palma et al. 2009 suggested to extend the diatom test to detect drowning by taking into consideration other groups of phytoplanktons. They have standardized the methods for recovery of microalgae from drowned victims by using different extraction procedures and concluded that dinoflagellates and some chlorophytes have cell walls and other resistant structures similar to diatoms. As a result, these organisms can be found in tissues of drowned victims.
Phytoplanktons are the photoautotrophic organisms which prevail in all types of water bodies such as streams, lakes, rivers, and ponds and are an important component of the food chain in the aquatic environment. Phytoplankton groups may be distinguished from each other based on a combination of characteristics, including photosynthetic pigments, shape, size and cell covering. They are microscopic in nature and "invisible" to perpetrators of crimes, thus it helps in linking a suspect to the crime scene (Siver et al. 1994).

Keeping in mind the needs of environmental and forensic experts, the present study has been undertaken to study the phytoplankton diversity along with seasonal variations in two forensically important ponds (Braham Sarovar and Prithus Pools) of Kurukshetra region of $\mathrm{Ha}-$ ryana, India. These two ponds are forensically important because of two reasons: Firstly, sufficiently large amount of water remains in these unguarded ponds throughout the year, and secondly, a large crowd gathers around them to take a dip during the year on many occasions. The data generated in the present study has been used to generate Phytoplankton-maps (P-maps). The characteristics Phytoplankton-maps of these two water bodies will hopefully help in unfolding the mysteries of deaths due to drowning and the data generated can be utilized as a reference data for determining the exact site of drowning.

\section{Material and methods}

\section{Selection of sampling sites}

In the present study the following two sites which are situated in Kurukshetra city and Pehowa city of Haryana, India have been selected to collect samples for the analysis of phytoplanktons:

\section{Brahma Sarovar}

It is the largest man-made water body situated in historically important Kurukshetra city, Haryana state, India

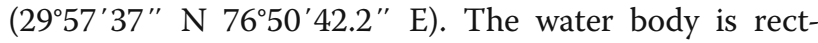
angular in shape, measuring $3600 \mathrm{ft}$ long, $1500 \mathrm{ft}$ wide and $15 \mathrm{ft}$ deep. It has religious significance, every year on 'Somavati Amavasya'(a special day in Hindu religion) and on the occasion of solar eclipses; millions of people from different parts of India visit this water body to take a holy bath (Fig. 1).

\section{Prithus pool}

It is located in another religiously important city, Pehowa city, Haryana, India (29 $\left.58^{\prime} 51.6^{\prime \prime} \mathrm{N} 76^{\circ} 34^{\prime} 464^{\prime \prime} \mathrm{E}\right)$ about $25 \mathrm{Kms}$ from Braham Sarovar. It was constructed by king Prithu after the death of his father. This place is known for funeral ceremonies (pind daan in Hindu religion), therefore, thousands of pilgrims from different places visit this pool throughout the year (Fig. 2). 


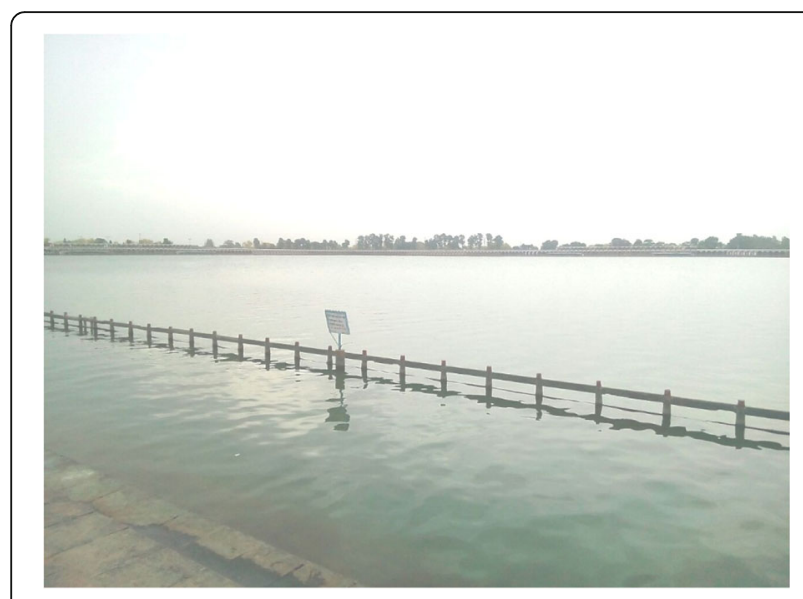

Fig. 1 Photograph of Braham Sarovar

\section{Collection of samples}

For phytoplankton analysis, the water samples have been collected during four seasons such as summer (MayJune), autumn (August-September), winter (NovemberDecember) and spring (February-March) from two selected sites from the year 2014 to 2016. The water samples were collected in a sterilized plastic bottle of 11 capacity and preserved in $4 \%$ formaldehyde solution.

\section{The procedure adopted to prepare slides for the analysis of phytoplankton}

- Approximately, $50 \mathrm{ml}$ of water sample was taken in a beaker and digested with $10 \mathrm{ml}$ of $5 \% \mathrm{HCl}$ for $24 \mathrm{~h}$.

- Next day, after thorough mixing of the water sample and $\mathrm{HCl}, 10 \mathrm{ml}$ of water sample was taken in a centrifuge tube and centrifuged at $3000 \mathrm{rpm}$ for $10 \mathrm{~min}$. The supernatant was collected out, leaving

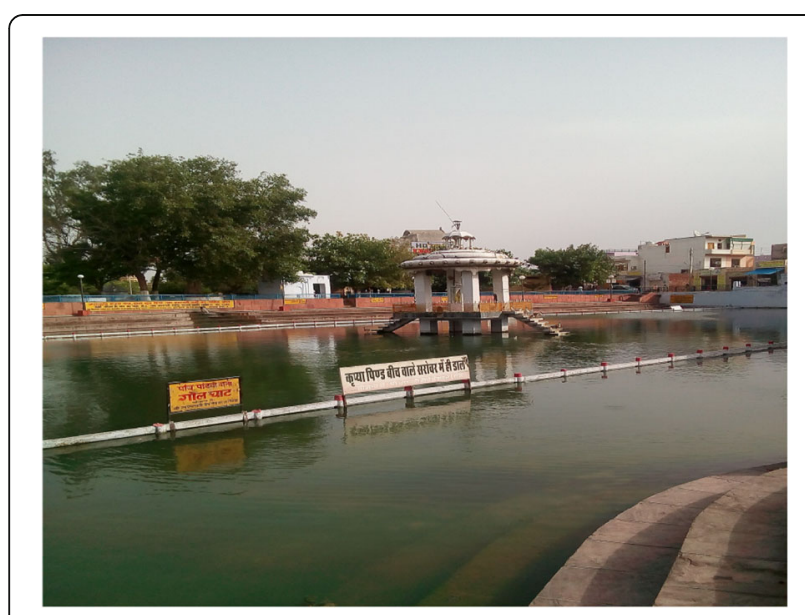

Fig. 2 Photograph of Prithus Pool behind only a residual material at the bottom of the tube.

- An excess of water was again mixed with residual material and centrifuged again as above. This process was repeated twice.

- After discarding the supernatant, the residual material (pellet) containing phytoplankton was poured over two sets of five serially marked (I-V) microscopic slides and smear was prepared. Then, these slides of two sets were permanently mounted using a high refractive index mounting material DPX to study diatoms and Glycerin jelly for phytoplankton analysis under the low and high power of the microscope.

\section{Analysis of slides prepared}

All the slides prepared for both the water bodies season wise have been examined with the help of an optical compound microscope (Nikon Eclipse microscope) fitted with light source under low $(10 \times \mathrm{X} 10 \times)$, high power $(10 \times X 40 \times)$ and oil immersion $(10 \times$ X 10×) magnifications. Nikon E200 series digital camera which has been attached to the microscope was used to prepare Photomicrographs for each and every phytoplankton species. These Photomicrographs were used for taxonomic identifications of phytoplankton with the help of publications given by Prescott (1962); Komárek et al. (1983); Desikachary (1959); Philipose (1967) and Wehr et al. (2015).

Data so obtained have been used to construct a phytoplankton map (p-map) for the both water bodies. Enumeration of phytoplankton was done by using Haemocytometer. The colonial and filamentous microalgae such as Microcystis sp., Merismopedia sp. and Oscillatoria sp. have been counted by using plating method (Stanier et al. 1971). Average of two years (2014-2016) data has been given in Tables 1, 2 and 3 .

\section{Physico-chemical properties}

In the both selected water bodies, the parameters such as total alkalinity, chloride and calcium levels, and total hardness have been determined according to APHA (American Public Health Association) manual (APHA 2005). Sodium and potassium contents in the water samples have also been determined with the help of flame photometer. Electrical conductivity, $\mathrm{pH}$, and temperature have also been determined by using the $\mathrm{pH}$ meter cum conductivity meter (Aquapro digital water tester model AP-2). TDS has been determined by using TDS meter (Aquapro digital water tester model AP-1). The correlation between physico-chemical parameters and phytoplankton species was carried out by Principal Component Analysis (PCA) using the Microsoft Excel Add-Ins software XLSTAT. 
Table 1 List of phytoplankton species observed in Braham Sarovar and Prithus Pools

\begin{tabular}{|c|c|c|}
\hline Family & Braham Sarovar & Prithus pool \\
\hline Chlorophyceae & $\begin{array}{l}\text { Ankistrodesmus spiralis, Ankistrodesmus fusiformis, Ankistrodesmus } \\
\text { flactum, Chlorococcum sp., Coelastrum microporum, Crucigenia } \\
\text { lauterbornii, Crucigenia tetrapedia, Dicloster acuatus, Krichneriella } \\
\text { sp., Monoraphidium arcuatum, Monoraphidium contortum, } \\
\text { Monoraphidium griffithi, Oocystis borgei, Oocytis marssonii, } \\
\text { Scenedesmus quadricauda, Scenedesmus dimorphus, Scenedesmus } \\
\text { ecornis, Scenedesmus bijugatus, Scenedesmus armatus } \\
\text { var.boglariensis, Scenedesmus abundans, Scenedesmus armatus } \\
\text { var.bicaudatus, Scenedesmus obliquus, Schroederia indica, } \\
\text { Staurastrum iotanum, Staurastrum sp. Lemmermannia punctata, } \\
\text { Tetraedrone lobulatum, Tetraedrone trigonium, Tetrachlorella } \\
\text { alternans, Tetrastrum minimum, Trebouxia sp., Westella botryoides. }\end{array}$ & $\begin{array}{l}\text { Ankistrodesmus acicularis, Chlorocuccum scabellum, Coelastrum } \\
\text { cambricum, Coelastrum microporum, Coelastrum astroideum, } \\
\text { Coelastrum morus, Coelastrum pulchrum, Coelastrum sphaericum, } \\
\text { Crucigeniella neglecta, Crucigenia lauterbornii, Crucigenia crucifera, } \\
\text { Crucigeniella quadrata, Crucigenia tetrapedia, Dictyochloropsis } \\
\text { reticulata, Kirchneriella irregularis, Monoraphidium contortum, } \\
\text { Monoraphidium fontinale, Monoraphidium arcuatum, } \\
\text { Monoraphidium griffithii, Oocystis sp., Oocystis solitaria, Pediastrum } \\
\text { duplex, Pediatrum simplex, Scenedesmus bijugatus, Scenedesmus } \\
\text { dimorphus, Scenedesmus abundans, Scenedesmus verrucosus, } \\
\text { Scenedesmus accuminatus, Scenedesmus caudato-aculeolatus, } \\
\text { Scenedesmus obliquus var. dimorphus, Scenedesmus quadricauda, } \\
\text { Schroederia setigera, Selenastrum sp., Tetracystis sp., Tetraedrone } \\
\text { minimum, Tetraedrone puchtatum, Tetraedron trigonium. }\end{array}$ \\
\hline Cyanophyceae & $\begin{array}{l}\text { Aphanocapsa sp., Calothrix sp., Chroococcus cohaerens, } \\
\text { Chroococcus dispersus, Cylindrospermum sp., Gloeocapsa } \\
\text { minimum, Merismopedia glauca, Merismopedia minima, } \\
\text { Microcystis panniformis, Microcystis aerognosa, Oscillatoria } \\
\text { agardhii, Geitlerinema pseuriaccutissimum, pseudoanabena } \\
\text { sp.,Synechococcus sp., Synechocystis aqualis }\end{array}$ & $\begin{array}{l}\text { Planktosphaeria gelatinosa, Aphanocapsa annulata, Aphanocapsa } \\
\text { delicatissima, Planktothrix maougetti, Merismopedia tenuissima, } \\
\text { Scytonema hofmanni, Spirulina sp., Synechococcus sp., Oscillatoria } \\
\text { agardhii, Oscillatoria rufringe, Oscillatoria limosa, Arthrospira } \\
\text { jenneri, Leptolyngbya granuliferat, Geitlerinema amphibium }\end{array}$ \\
\hline Bacillariophyceae & $\begin{array}{l}\text { Aulacoseira granulata, Cymbella tumida, Epithemia turgida, } \\
\text { Eunotia rhomboidea, Navicula capitoradiata, Nitzchia palecea, } \\
\text { Nitzchia accicularis, Cymbella laevis, Stephanocyclus } \\
\text { meneghiniana, Pinnularia abaujensis, Navicula cryptocephala, } \\
\text { Gomphonema truncatum }\end{array}$ & $\begin{array}{l}\text { Frustulia vulgaris, Cymbella cistula, Melosira varians, Nitzschia } \\
\text { palea, Nitzschia acicularis, Cymbella cymbiformis, Navicula } \\
\text { gregaria }\end{array}$ \\
\hline Euglenophyceae & $\begin{array}{l}\text { Euglena sp., Lepcinclis fusiformis, Phacus longicauda, Phacus } \\
\text { tortus, Trachelomonas horrida. }\end{array}$ & $\begin{array}{l}\text { Lepocinclis ovum, Phacus onxy, Phacus pyrum, Euglena acus, } \\
\text { Trachelomonas langerdiana, Euglena caudata,Euglena virdis, } \\
\text { Lepocinclis elongata, Lepocinclis sternii, Euglena splendens. }\end{array}$ \\
\hline Dinophyceae & $\begin{array}{l}\text { Alexanderium catenella, Alexanderium insuetum, Gonyaulax } \\
\text { lingulodinium, Gyrodinium fusus, Peridinium cinctum, Peridinium } \\
\text { umbonatum. }\end{array}$ & \\
\hline
\end{tabular}

Diversity indices: In the present study, the diversity indices of phytoplankton species have been calculated in terms of

- Species diversity method given by Shannon (2001),

- Species richness by Menhinick (1964) and

- Evenness by Pielou (1975) as follows:

Shannon-Wiener diversity index: Shannon diversity index is a quantitative measure of species diversity in a community and can be calculated as follows:

$$
\mathbf{H}=-\sum(\mathbf{p i}) \log 2 \mathbf{p i}
$$

Where, $\mathrm{H}=$ Shannon and Weaver diversity index. $\mathrm{pi}=\mathrm{ni} / \mathrm{N}$, ni being the number of individual of ith species and.

$\mathrm{N}=$ total number of individuals in the sample.

Species Richness: Species richness is a count of a number of species in a water body. It is calculated using the following formula:

$$
\mathbf{D}=\mathbf{n} / \sqrt{ } \mathbf{N}
$$

Where $\mathrm{D}=$ Species Richness, $\mathrm{n}=$ total number of species in a sample.

$\mathrm{N}=$ Total number of an individual organism in a sample.

Species Evenness: Species evenness is the measures of how equals the relative abundance of different species

Table 2 Phytoplankton density (individuals $\times 10^{3} \mathrm{~mL}^{-1}$ ) in Braham Sarovar during different seasons

\begin{tabular}{lllll}
\hline Class & Summer & Autumn & Winter & Spring \\
\hline Chlorophyceae & $1.180 \pm 0.235$ & $0.716 \pm 0.206$ & $0.357 \times 0.225$ & $0.653 \pm 0.234$. \\
Cyanophyceae & $0.372 \pm 0.090$ & $0.322 \pm .092$ & $0.714 \pm 0.091$ & $0.344 \pm 0.293$ \\
Bacillariophyceae & $0.188 \pm 0.10$ & $0.077 \pm 0.03$ & $0.256 \pm 0.068$. & $0.190 \pm 0.08$ \\
Euglenophyceae & 0 & $0.05 \pm 0.032$ & $0.024 \pm 0.02$ & 0 \\
Dinophyceae & 0 & 0 & $0.012 \pm 0.01$ & $0.098 \pm 0.05$ \\
Total & $1.740 \pm 0.52 .6$ & $1.162 \pm 0.3$ & $1.363 \pm 0.28$ & $1.285 \pm 0.24$ \\
\hline
\end{tabular}


Table 3 Phytoplankton density (individuals $\times 10^{3} \mathrm{~mL}^{-1}$ ) in Prithus Pool during different seasons

\begin{tabular}{lllll}
\hline Class & Summer & Autumn & Winter & Spring \\
\hline Chlorophyceae & $1.387 \pm 0.27$ & $1.078 \pm 0.22$ & $0.909 \pm 0.11$ & $1.372 \pm 0.37$ \\
Cyanophyceae & $0.346 \pm 0.14$ & $0.243 \pm 0.006$ & $0.178 \pm 0.08$ & $0.231 \times \pm 0.06$ \\
Bacillariophyceae & $0.192 \pm 0.024$ & $0.051 \pm 0.034$ & $0.205 \pm 0.03$ & $0.128 \pm 0.058$ \\
Euglenophyceae & $0.063 \pm 0.057$ & $0.026 \pm 0.019$ & $0.101 \pm 0.07$ & $0.138 \pm 0.04$ \\
Total & $1.988 \pm 0.525$ & $1.398 \pm 0.42$ & $1.393 \pm 0.32$ & $1.869 \pm 0.52$ \\
\hline
\end{tabular}

are in a community. It is calculated using formula as follows:

$$
\mathbf{J}=\mathbf{H} / \log 2(\mathbf{S})
$$

Where, $\mathrm{J}=$ Evenness $\mathrm{H}=$ Shannon and Weaver diversity index.

$\mathrm{S}=$ Total number of species in a sample.

\section{Phytoplankton-maps (P-maps)}

The data generated in the present study were used to prepare the P-maps (Tables 4 and 5) of two selected water bodies (Braham Sarovar and Prithus Pools). The P-maps depicts the detailed list of phytoplankton genera and species present in the two selected water bodies.

P-maps have been divided into three parts- A, B, and $\mathrm{C}$ as shown in Tables 4 and 5 . In part - A, phytoplanktons species have been shown, which have been divided into the following four categories:

- Commonly found phytoplanktons

- Site-specific phytoplanktons,

- Seasonally occurring species of phytoplanktons

- Rarely occurring phytoplankton

The detailed information about these categories has been given below and is helpful in generating P-map for a specific water body:

* Commonly found species: Commonly found species are those which are common in more than one water body. They have significance in detecting the death due to drowning and are of little significance in diagnosing drowning site.

* Site-specific species: Site-specific species are those which are restricted to a particular water body, hence they have great forensic significance in locating the exact site of drowning, particularly when a body is found away from the actual site of drowning and also they help in linking the suspect and victim to the crime scene.

* Seasonally occurring species: This category includes those species which are dominant in one season and may become extinct or dominated by other species during another season in a particular water body.
These season specific species of a particular water body may help in determining the season of occurrence of crime.

* Rarely occurring species: These are those species which are found occasionally or by chance in a particular water body. These species are not important from the forensic point of view.

In part-B of $\mathrm{P}$-map for both the water bodies, the photomicrographs of Site-specific species have been shown (Tables 4 and 5), whereas part - $\mathrm{C}$ shows Distribution of Phytoplankton species during the different season in both water bodies (Tables 4 and 5).

\section{Results and discussion}

Phytoplanktons are the diverse group of photosynthetic organisms present in all the aquatic habitats such as lakes, rivers, ponds, canals, sea etc. Moreover, they have different shapes, sizes, colors and forms, which provide them individuality. So their presence in water bodies and potential to identify the site of drowning may help in the forensic investigation. Because of their microscopic nature and invisibility phytoplankton may adhere to the suspect, victim or their clothes or weapon of offense. In addition, different species of phytoplankton present during different seasons which aids in linking the suspect to a particular crime scene during the specific season (Hall 1997). Therefore, seasonal variation of phytoplankton has been studied in two selected water bodies of Kurukshetra region, continuously for two years to generate a baseline database of phytoplankton (Phytoplankton maps) for each water body.

In the present study, remarkable changes in diversity and abundance of phytoplankton have been observed during different seasons. In Braham Sarovar and Prithus Pools, a total of 138 species belonging to 59 phytoplankton members have been found (Tables 1 and 6). Individually in Braham Sarovar alone 47 genera belonging to 5 classes i.e. Cyanophyceae (12), Chlorophyceae (18), Bacillariophyceae (9), Euglenophyceae (4) and Dinophyceae (4) representing 70 species have been found. Similarly, in Prithus pool, 36 genera belonging to 4 classes' i.e. Chlorophyceae (15), Cyanophyceae (12), Euglenophyceae (4), and Bacillariophyceae (5) representing 68 species found. Similar studies have been conducted by Kim 2011. He observed 16 species of diatoms, 20 species of 
Table 4 Phytoplankton -map (P-maps) of Braham Sarovar

\begin{tabular}{|c|c|c|c|c|}
\hline \multirow{2}{*}{\multicolumn{5}{|c|}{$\begin{array}{lcc}\text { Commonly occurring } & \text { Site- specific } & \text { Seasonally occuring } \\
\text { Part A: List of phytoplanktons genera and species observed in Braham Sarovar }\end{array}$}} \\
\hline & & & & \\
\hline \multirow{4}{*}{$\begin{array}{l}\text { Coelastrum microporum,Crucigenia } \\
\text { lauterbornii, Crucigenia } \\
\text { tetrapedia,Monoraphidium arcuatum, } \\
\text { Monoraphidium contortum, } \\
\text { Monoraphidium griffithi, Nitzschia } \\
\text { acicularis,Oscillatoria agardhii, } \\
\text { Scenedesmus abundans, Scenedesmus } \\
\text { dimorphus, Scenedesmus } \\
\text { obliquus,Tetraedron minimum, } \\
\text { Tetraedron trigonium }\end{array}$} & \multirow[t]{4}{*}{$\begin{array}{l}\text { Epithemia turgida, } \\
\text { Eunotia rhomboidea, } \\
\text { Westella botryoides, } \\
\text { Cylindrospermum sp. }\end{array}$} & Summer & $\begin{array}{l}\text { Gloeocapsa sp., Ankistrodesmus fusiformis, } \\
\text { Monoraphidium arcuatum, Scenedesmus } \\
\text { obliquus, Tetraedron minimum, } \\
\text { Staurastrum iotanum, Choroococcus } \\
\text { coherens, Chroococcus dispersus, Nitzschia } \\
\text { palecea, Merismopedia minima, Gleocapsa } \\
\text { minimum, Pinnularia abaujensis. }\end{array}$ & \multirow{4}{*}{$\begin{array}{l}\text { Chlorococcum sp., Crucigenia } \\
\text { lauterborni, Dicloster acuatus Gloeocystis } \\
\text { sp.,Monoraphidium contortum,Oocystis } \\
\text { borgei, Schroederia indica, Staurastrum } \\
\text { sp., Tetrachlorella alternans, Tetraedron } \\
\text { lobulatum, Trebauxia sp., Geitlerinema } \\
\text { pseuriaaccutissimum, Microcystis } \\
\text { panniformis, Navicula capitoradiata, } \\
\text { Lepocinclis fusiformis, Lemmermannia } \\
\text { punctata,Phacus longicauda, Phacus } \\
\text { tortus, Ttrachelomonas horrida, } \\
\text { Alexanderium acatenella, Alexanderium } \\
\text { insuetum, Gonyaulax lingulodinium, } \\
\text { Gyrodinium fusus, Peridinium cinctum, } \\
\text { Peridinium umbonatum. }\end{array}$} \\
\hline & & Autumn & $\begin{array}{l}\text { Ankistrodesmus fusiformis, Crucigenia } \\
\text { Tetrapedia, Monoraphidium griffthii, } \\
\text { Lemmermannia punctata. }\end{array}$ & \\
\hline & & Winter & $\begin{array}{l}\text { Merismopedia glauca, Microcsystis } \\
\text { aerognosa, Synechococcus sp., } \\
\text { Kritchneriella irregularis, Gomphonema } \\
\text { truncata, Navicual cryptocephala, } \\
\text { Epithemia turgida, Eunotia rhomboidea, } \\
\text { Cylindrospermumsp }\end{array}$ & \\
\hline & & Spring & $\begin{array}{l}\text { Aphanocapsa sp., Oosystis marsonnii, } \\
\text { Scenedesmus bijugatus, Scenedesmus } \\
\text { armatus, Pseudoanabaena constrictum }\end{array}$ & \\
\hline
\end{tabular}

Part B: Photomicrographs of some of site-specific species.

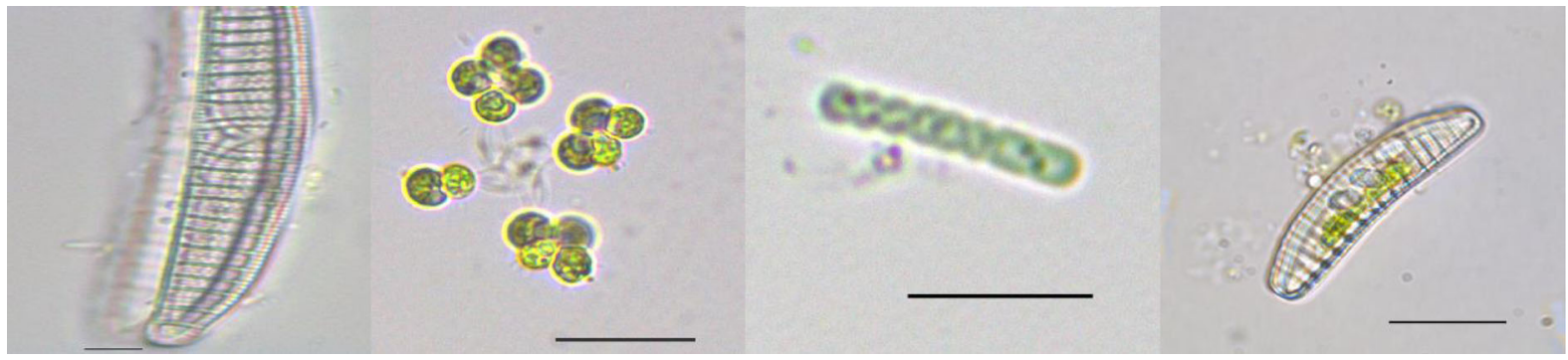

Epithemia turgida, Westella botryoides, Cylindrospermum sp. Eunotia rhomboidea

Part C: Distribution of Phytoplankton during different seasons
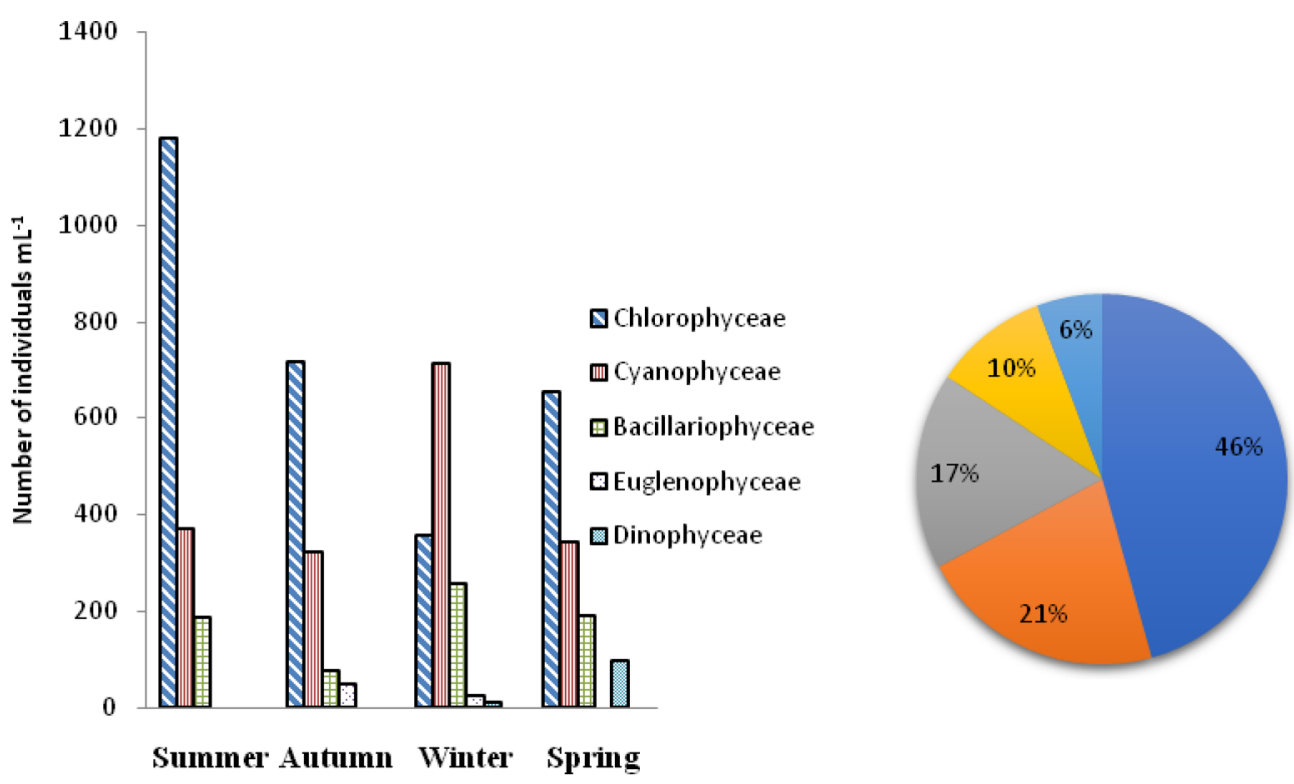

- Chlorophyceae

- Cyanophyceae

- Bacillariophyceae

$\square$ Dinophyceae

- Euglenophyceae 
Table 5 Phytoplankton -map (P-map) for Prithus Pool

\begin{tabular}{|c|c|c|c|c|}
\hline \multirow{2}{*}{\multicolumn{5}{|c|}{$\begin{array}{l}\text { Commonly occurring } \quad \text { Site- specific } \quad \text { Seasonally occuring } \\
\text { Part A: List of phytoplanktons genera and species observed in Prithus Pool }\end{array}$}} \\
\hline & & & & \\
\hline \multirow[t]{4}{*}{$\begin{array}{l}\text { Coelastrum microporum, Crucigenia } \\
\text { lauterbornii, Crucigenia } \\
\text { tetrapedia,Monoraphidium arcuatum, } \\
\text { Monoraphidium contortum, } \\
\text { Monoraphidium griffithi, Nitzschia } \\
\text { acicularis,Oscillatoria agardhii, } \\
\text { Scenedesmus abundans, } \\
\text { Scenedesmus } \\
\text { dimorphus, Scenedesmus } \\
\text { obliquus,Tetraedron } \\
\text { minimum,Tetraedron trigonium. }\end{array}$} & \multirow[t]{4}{*}{$\begin{array}{l}\text { Leptolynbya } \\
\text { granulifer, Arthospira } \\
\text { jenerii,Cymbella } \\
\text { cymbiformis } \\
\text { Frustulia vulgaris. }\end{array}$} & Summer & $\begin{array}{l}\text { Coelastrum microporum, Crucigenia } \\
\text { quadrata, Tetraedrone minimum, } \\
\text { Chlorococcum sp., Coelastridium } \\
\text { asterodeum, Crucigeniella quadrata, } \\
\text { Selenastrum sp., Aphanocapsa } \\
\text { delicattissima, Geitlerinema amphibium, } \\
\text { Syctonema hofmanii, Melosira varians, } \\
\text { Trachelomonas langerdiana, } \\
\text { Scenedesmus quadricauda }\end{array}$ & \multirow{4}{*}{$\begin{array}{l}\text { Ankistrodesmus acicularis, } \\
\text { Ankistrodesmus flactum, Coelastrum } \\
\text { astroideum, Coelastrum morus, } \\
\text { Coelastrum pulchrum, Coelastrum } \\
\text { morus, Crucigeniella neglecta, } \\
\text { Pediastrum duplex, Pediatrum simplex, } \\
\text { Schroederia setigera,Geitlerinema } \\
\text { amphibium,Oscillatoria limosa, } \\
\text { Navicula gregaria, Euglena caudata, } \\
\text { Euglena splendens, Euglena virdis, } \\
\text { Lepocinclis elongata, Lepocinclis sternii, } \\
\text { Phacus onxy. }\end{array}$} \\
\hline & & Autumn & $\begin{array}{l}\text { Oocystis solitare, Scenedesmus } \\
\text { versucois, Scenedesmus acumnatus, } \\
\text { Oscillatoria rufringe, Planktothrix } \\
\text { mougetti, Lepocinclis ovum. }\end{array}$ & \\
\hline & & Winter & $\begin{array}{l}\text { Tetracystis sp., Kirchneriella sp., } \\
\text { Coelastrum asterodeum, Tetracystis sp., } \\
\text { Cymbella cistulla, Phacus pyrum }\end{array}$ & \\
\hline & & Spring & $\begin{array}{l}\text { Chlorococcum scabellum, Coelastrum } \\
\text { cambricum, Dictyochoropsis reticulata, } \\
\text { Monoraphidium frontinale, Crucigenia } \\
\text { crucifera, Scenedesmus bijugatus, } \\
\text { Scenedesmus caudato-aculeolatus, Tet } \\
\text { raedrone punchtatum, Oscillatoria } \\
\text { agardhii }\end{array}$ & \\
\hline
\end{tabular}

Part B: Photomicrographs of some of site-specific species

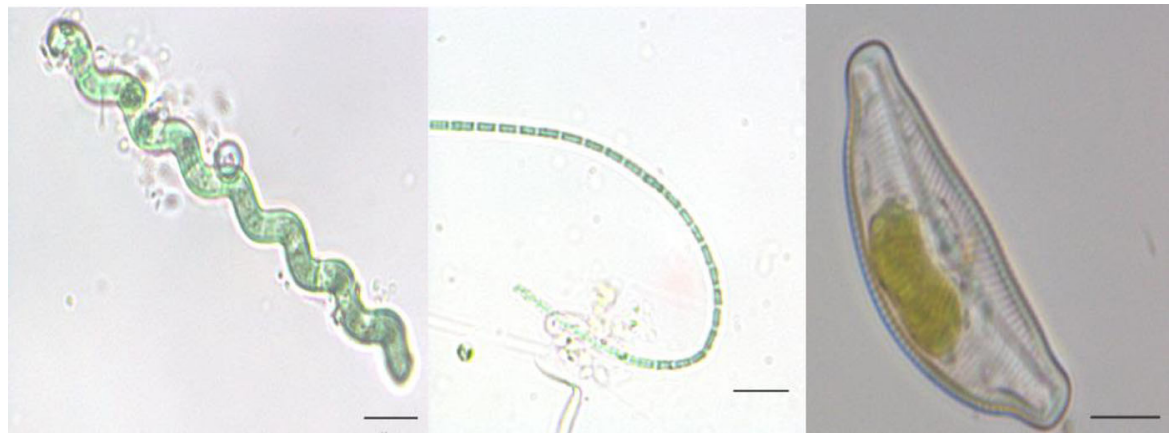

Arthospira jenerii,
Leptolynbya granulifer, Cymbella cymbiformis.

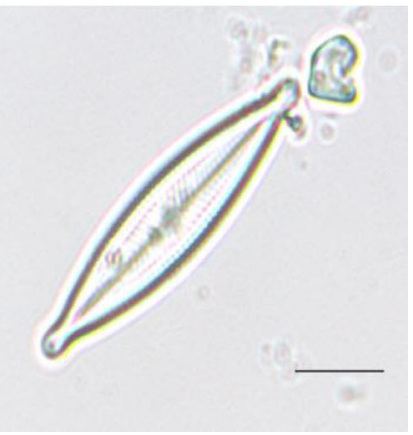

Frustulia vulgaris

Part C: Distribution of Phytoplankton during different seasons
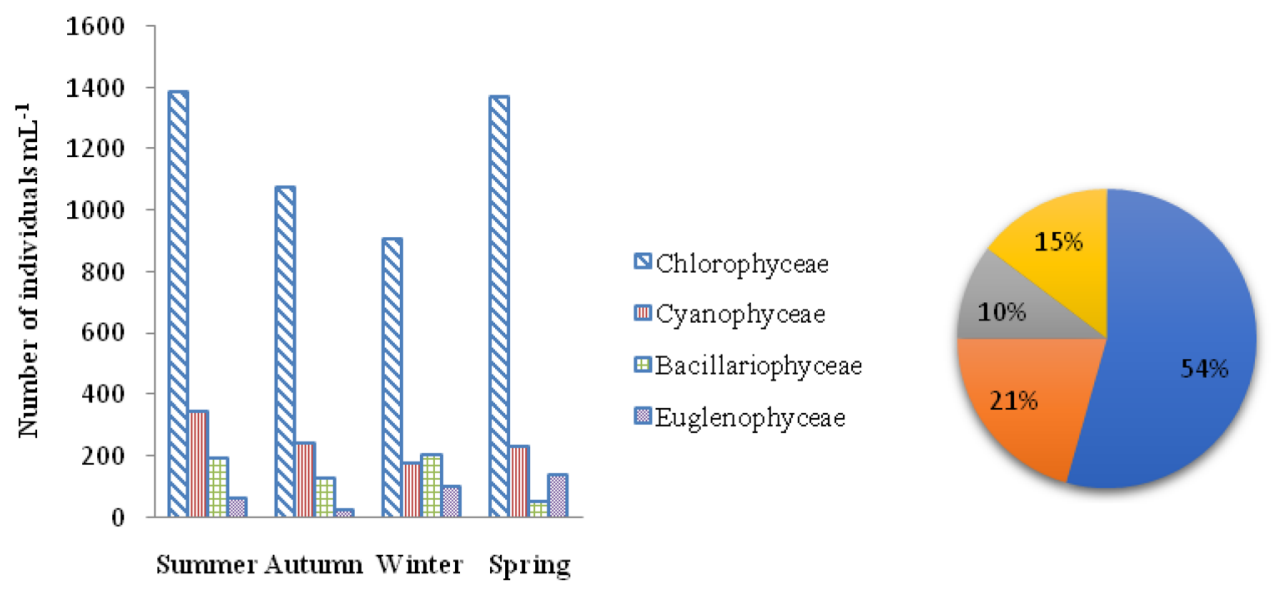

- Chlorophyceae

- Cyanophyceae

- Bacillariophycea

Euglenophyceae 
Table 6 List of genera observed in Braham Sarovar and Prithus Pools

\begin{tabular}{lcc}
\hline S. No Genus & Braham Sarovar & Prithus Pool \\
\hline Genus related to class Chlorophyceae &
\end{tabular}

\begin{tabular}{|c|c|}
\hline 1. & Ankistrodesmus \\
\hline 2. & Chlorococcum \\
\hline 3. & Coelastrum \\
\hline 4. & Crucigeniella \\
\hline 5. & Crucigenia \\
\hline 6. & Dicloster \\
\hline 7. & Dictyochloropsis \\
\hline 8. & Gloeocystis \\
\hline 9. & Kirchneriella \\
\hline 10. & Monoraphidium \\
\hline 11. & Lemmermannia \\
\hline 12. & Oocystis \\
\hline 13. & Pediastrum \\
\hline 14. & Scenedesmus \\
\hline 15. & Schroederia \\
\hline 16. & Selenastrum sp \\
\hline 17. & Staurastrum \\
\hline 18. & Tetrachlorella \\
\hline 19. & Tetracystis \\
\hline 20. & Tetraedrone \\
\hline 21. & Trebouxia \\
\hline 22. & Westella \\
\hline 23. & Planktosphaeria \\
\hline
\end{tabular}

Genus related to class Cyanophyceae

$\begin{array}{ll}\text { 24. } & \text { Aphanocapsa } \\ \text { 25. } & \text { Arthrospira } \\ \text { 26. } & \text { Calothrix } \\ \text { 27. } & \text { Chroococcus } \\ \text { 28. } & \text { Cylindrospermum } \\ \text { 29. } & \text { Geitlerinema } \\ \text { 30. } & \text { Gloeocapsa } \\ \text { 31. } & \text { Leptolyngbya } \\ \text { 32. } & \text { Merismopedia } \\ \text { 33. } & \text { Microcystis } \\ \text { 34. } & \text { Oscillatoria } \\ \text { 35. } & \text { Planktothrix } \\ \text { 36. } & \text { Pseudanabaena } \\ \text { 37. } & \text { Scytonema } \\ \text { 38. } & \text { Spirulina } \\ \text { 39. } & \text { Synechococcus } \\ \text { 40. } & \text { Synechocystis }\end{array}$

Table 6 List of genera observed in Braham Sarovar and Prithus Pools (Continued)

\begin{tabular}{|c|c|c|c|}
\hline S. No & Genus & Braham Sarovar & Prithus Pool \\
\hline \multicolumn{4}{|c|}{ Genus related to class Euglenophyceae } \\
\hline 41. & Euglena & + & + \\
\hline 42. & Lepocinclis & + & + \\
\hline 43. & Phacus & + & + \\
\hline 44. & Trachelomonas & + & + \\
\hline \multicolumn{4}{|c|}{ Genus related to class Bacillariophyceae } \\
\hline 45. & Aulacoseira & + & - \\
\hline 46. & Cymbella & + & + \\
\hline 47. & Epithemia & + & - \\
\hline 48 & Eunotia & + & - \\
\hline 49. & Frustulia & - & + \\
\hline 50. & Gomphonema & + & - \\
\hline 51. & Melosira & - & + \\
\hline 52. & Navicula & + & + \\
\hline 53. & Nitzschia & + & + \\
\hline 54. & Pinnularia & + & - \\
\hline 55. & Stephanocyclus & + & - \\
\hline \multicolumn{4}{|c|}{ Genus related to class Dinophyceae } \\
\hline 56. & Alexanderium & + & - \\
\hline 57. & Gonyaulax & + & \\
\hline 58. & Gyrodinium & + & - \\
\hline 59. & Peridinium & + & - \\
\hline
\end{tabular}

green algae, 6 species of Cyanobacteria and 6 species of other algae in three aquatic locations of Gwang-ju area (South Korea) where drowned victims were found.

The detailed list of species recovered in the present study has been given in Table 1 . Figures 3 and 4 show photomicrographs of different species of phytoplankton observed in Braham Sarovar and Prithus pools water bodies.

\section{Phytoplankton community \\ Class - Chlorophyceae}

The members of Chlorophyceae formed the most dominant group among others in both water bodies which accounted for $46 \%$ of total phytoplankton diversity with 32 species in the Braham Sarovar (Table 4c) and 54.4\% of total diversity was represented by 37 species of Chlorophyceae in the Prithus Pool (Table 5c). Panigrahi and Patra (2013) also reported dominance of Chlorophyceae over other phytoplankton groups in terms of numerical value and percentage composition in a water body of Cuttack city, West Bengal, India. The dominant species of Braham Sarovar were Ankistrodesmus fusiformis, Ankistrodesmus flactum, Crucigenia tetrapedia, Oocystis marsonii, Scenedesmus bijugatus, Scenedesmus abundance, Tetrastrum minimum, Coelastrum Microporum. 


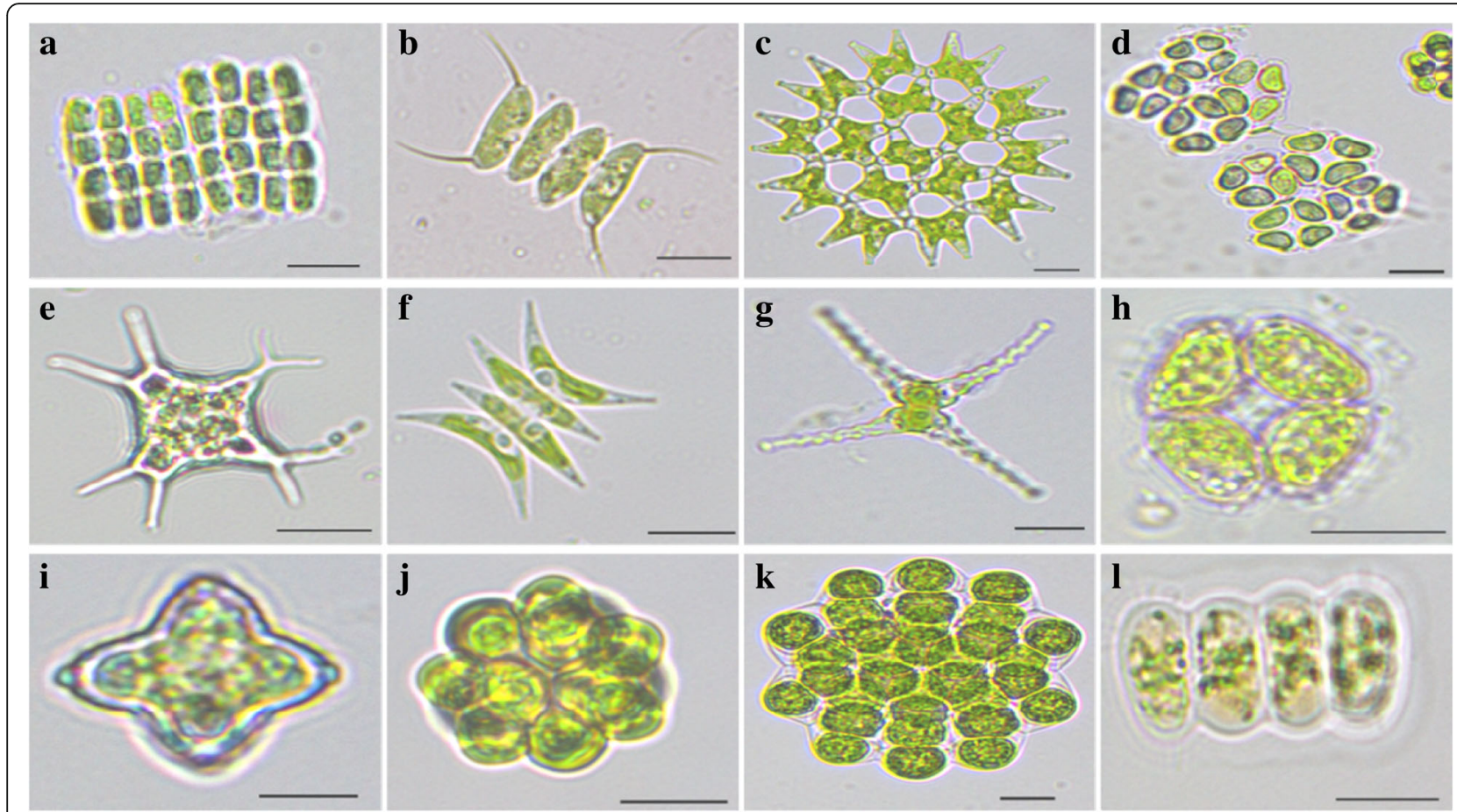

Fig. 3 Photomicrograph of phytoplankton observed during the present study. a. Crucigeniella quadrata, b. Scenedesmus opaliensis, c. Pediastrum duplex, d. Crucigeniella crucifera, e. Tetraedron lobulatum, f. Scenedesmus dimorphus $\mathbf{g}$. Staurastrum iotanum, h. Crucigenia fenestrata, i. Tetraedron minimum, j. Coelastrum microporum, k. Coelastrum cambricum, I. Scenedesmus bijugatus. Scale bar, 10 $10 m$

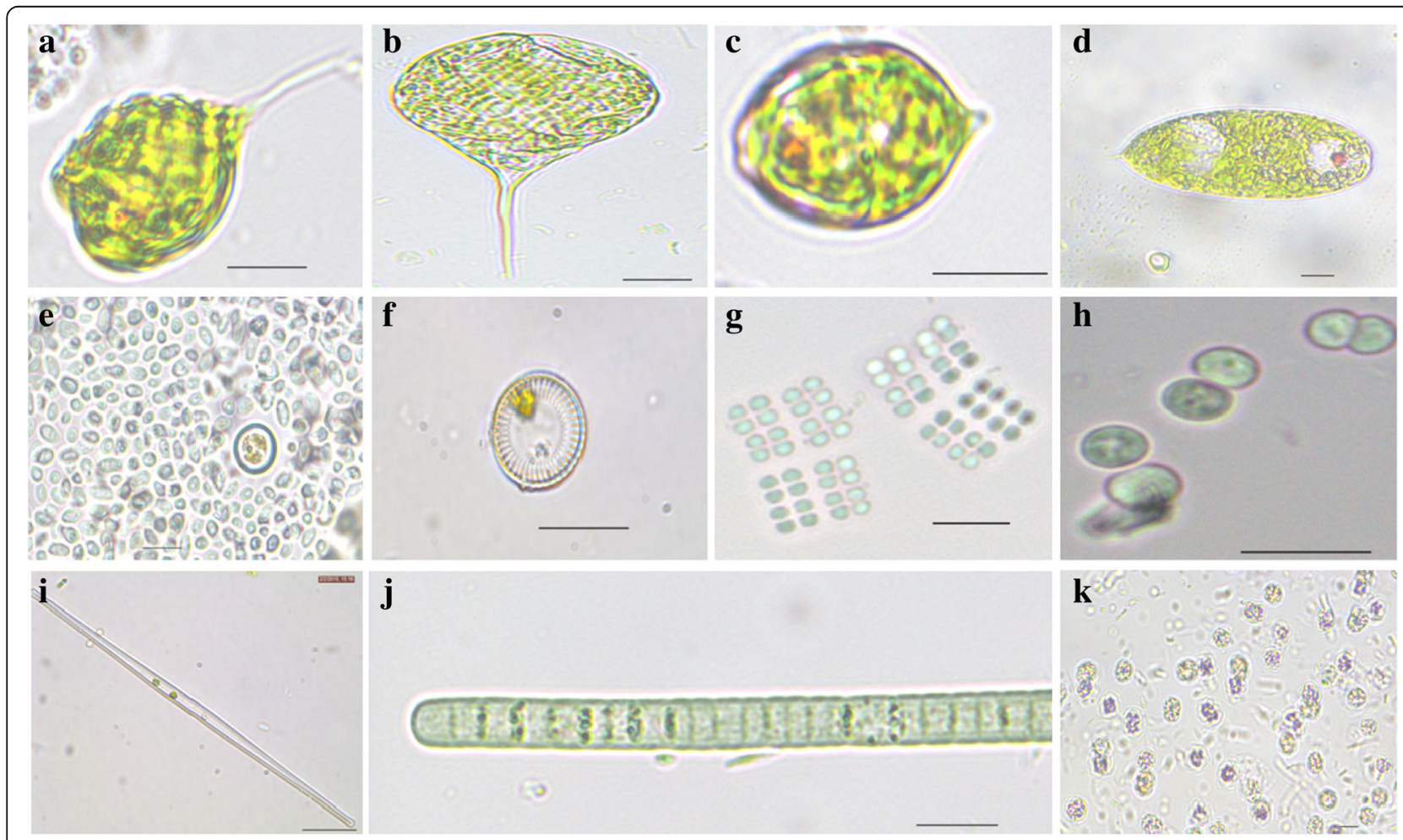

Fig. 4 Photomicrograph of phytoplankton observed during the present study a. Phacus pyrum, b. Phacus longicauda, $\mathbf{c}$. Lepocinclis fusiformis, $\mathbf{d}$. Euglena splendens, e. Synechococcus sp., f. Stephanocyclus meneghiniana g. Merismopedia minima, h. Synechocystis aquatilis, i. Nitzschia acicularis, j. Oscillatoria limosa, k. Microcystis aeruginosa.Scale bar,10 $\mu \mathrm{m}$ 
In Prithus pool the most dominant species were Chlorococcum scabellum, Coelastrum microporum, Coelastrum asteriodeum, Crucigenia crucifera, Crucigenia tetrapedia, Crucigeniella quadrata, Crucigeniella reticulata, Dictyochloropsis reticulata Kritchnella sp., Scenedesmus dimorphus, Scenedesmus obliquus, Scenedesmus quadricauda, and Tetradron puchtatum.

\section{Class-Cyanophyceae}

Cyanophyceae was the second most abundant group in the Braham Sarovar with $21.4 \%$ diversity of the total phytoplankton population. Among the 15 species, Aphanocapsa sp., Chroococcus dispersus, Merismopedia glauca, Merismopedia minima, Microcystis aeruginosa and Synechococcus sp. were dominant ones.

Similarly, in Prithus pool, Cyanophycaeae also ranked as the second most abundant group accounting for $21 \%$ of the total population with 14 species (Tables $4 \mathrm{c}$ and 5c). The dominating species were found to be Merismopedia tenuiasima, Spirulina sp., Oscillatoria agardhii and, Plantothrix mougeotti.

\section{Class- Bacillariophyceae}

The class Bacillariophyceae has been ranked third in Braham Sarovar and accounted for $17.1 \%$ but the same class ranked fourth in Prithus Pool and accounted for $10.2 \%$ of total phytoplankton diversity found in this water body (Tables 4c and 5c). Total 12 species of diatoms have been found from the Braham Sarovar with Aulacoseira granulata, Nitzschia acicularis, Nitzschia palecea and Navicula cryptocephala being the dominant ones, whereas seven species of diatoms reported from Prithus pool Frustulia vulgaris, Melosira varians Frustulia vulgaris and Nitzschia palea were dominant.

\section{Class-Euglenophyceae}

Euglenophyceae class constituted around 15\% (10 species) of the total phytoplankton population and formed the third most dominant group in Prithus pool, whereas it ranked fifth in Braham Sarovar accounting for 6\% (5 species). Among them, Phacus longicauda, Phacus tortus and Lepocinclis fusiformis were the most abundant species in the Braham Sarovar, while Lepcinclis ovum, Euglena acus and Euglena virdis were dominant in Prithus pool (Tables 4c, 5c).

\section{Class-Dinophyceae}

Members of Dinophyceae have been only observed in the Braham Sarovar water body and constituted 10\% (6 species) of species diversity with Peridinium cinctum being the dominant one.
Seasonal variation in phytoplankton population density Mean density of $1.662 \times 10^{3} \pm 227$ phytoplankton individuals $\mathrm{mL}^{-1}$ of water was observed at Prithus pool while in Braham Sarovar mean density has been calculated to be $1.388 \times 10^{3} \pm 248$ individuals $\mathrm{mL}^{-1}$. In both water bodies, Chlorophyceae was found to be the most abundant group in summer which declined in autumn and winter. A similar observation has been made by Shinde et al. (2012) in Harsool-savang dam, Aurangabad; where maximum density of Chlorophyceae was observed in summer season. Nowrouzi and Valavi (2011) while studying phytoplankton of Lake Kaftar in Iran also reported highest density of Chlorophyceae in summer and spring and the lowest in winter. Cyanophyceae in Prithus pool exhibited maximum growth in summer and minimum in winter while, in Braham Sarovar, Cyanophyceae exhibited maximum growth in winter and minimum in the autumn. The maximum density of Cyanophyceae in Braham Sarovar during winter was due to the overgrowth of Microcystis aeruginosa. Khuantrairong and Traichaiyaporn (2008) also observed Cyanophyta as the most abundant group in winter and summer in Doi Tao Lake, Thailand. On the contrary, Venkateswarlu (1969) reported the dominance of Cyanophyceae in summer season in Mossi River, Hyderabad. Singh and Swarup (1980) also reported maximum growth of cyanophyceae during summer in Lake Suraha, Uttar Pradesh. The maximum abundance of Bacillariophyceae was recorded in winter and minimum in autumn. Singh et al. (2010) observed highest density of Bacillariophyceae in winter in Mawatha lake Rajasthan. A similar trend has also been observed by Baba and Pandit (2014) while studying the diversity of phytoplankton in Wular Lake Kashmir. Members of Euglenophyceae were observed both in autumn and winter in Braham Sarovar, while in Prithus pool, members of Euglenophyceae were maximum during winter and spring and minimum in summer. The members of Dinophyceae were detected only in Braham Sarovar, that too during winter and spring season. Mean density distribution of different classes of phytoplankton in Braham Sarovar and Prithus Pools is Part-C of P-map and has been shown in Tables 4 and 5 .

Various environmental factors such as light, temperature and rainfall and physico-chemical factors $(\mathrm{pH}$, temperature, salinity, Nitrogen, Phosphate, Calcium, Sodium, Phosphate, Chloride, etc) of a water body get changed with seasons which in turn bring about change in composition and abundance of phytoplankton (Figueredo and Giani 2009). In the present study, the maximum density of Chlorophyceae and Cynaophyceae has been recorded during the summer season and minimum during autumn and winter season. The increase in the density of phytoplankton may be attributed to the increase in temperature during 
summer, which not only increases the rate of photosynthesis, but also increases the concentration of available nutrients due to increase in water evaporation. Whereas a decrease in the density during autumn and winter may be due to the increase in the water level of the water body by rainwater which decreases the photosynthetic efficiency of phytoplanktons (Shinde et al. 2012). The density of Bacillariophyceae was observed maximum during winter which may be due to a higher rate of multiplication of Bacillariophyceae at low temperature (Raibole and Singh 2011). The members of Euglenophyceae were observed during autumn and winter season only, may be because of two reasons i.e. either they cannot tolerate higher temperature or increased accumulation of organic matter in the water bodies due to heavy rainfall, favors the growth of Euglenophyceae (Tiwari and Chauhan 2006).

\section{Diversity index}

High values of Shannon's index $\left(\mathrm{H}^{\prime}\right)$ were recorded during summer and lower during winter at both water bodies. Shannon's index has been calculated to be high (3.16 \pm 0.013$)$ in Braham Sarovar as compared to Prithus pool $(3.03 \pm 0.26)$ (Table 7). The value of Species richness of Braham Sarovar was comparatively high during summer (4.55) and minimum during winters (3.87) and autumn (3.96) while in Prithus pool, species richness was maximum during spring (3.86) and minimum during autumn (3.42). Species evenness in Prithus pool showed little variation during different seasons, indicating that all the species were equally distributed throughout the year. In Braham Sarovar, the highest value of species evenness was 0.93 during summer and lower during winter (0.86).

\section{Physico-chemical properties}

Physico-chemical parameters of Braham Sarovar and Prithus pools have been assessed to determine the tropical status of the water body and their co-relation with the phytoplankton species diversity. The physico-chemical parameters of Prithus pool were numerically high as compared to Braham Sarovar. The high value of physico-chemical parameters was probably due to the anthropogenic activity at this pond. The physic-chemical parameters of both aquatic bodies during the different seasons are shown in Tables 8 and 9.

\section{Correlation between physico-chemical parameters and phytoplankton community Principal component analysis (PCA)}

Principal Component Analysis (PCA) is a multivariate data analysis technique which reduces the multi-dimensional data into two principal components. In present study Principal Component Analysis has been used to establish the degree of correlation between physico-chemical parameters (as mentioned above) and the phytoplankton species prevailing in the water body. It helps to understand whether phytoplankton has a positive or negative relationship with different physico-chemical parameters and what are the key factors responsible for their growth and inhibition?

As in forensic investigations, it is common to find a dead body away from the actual site of drowning due to water current, tides, etc. Thus, determination of the actual site of drowning becomes important for the medico-legal expert. The abundance and diversity of phytoplankton vary between different water bodies due to the difference in various parameters such as $\mathrm{pH}$, temperature, salinity, electrical conductivity, hardness, alkalinity etc. of that water body (Nowrouzi and Valavi 2011). Some of the physico-chemical parameters are favorable for the growth of one species while these may not support growth of others. The different species of phytoplankton get established in a particular water body based on their preferences for particular physico-chemical components of water. Therefore, a positive test for drowning should not only be based upon the presence or absence of phytoplankton in the body of a drowned victim, rather it should also exhibit the same type of phytoplankton in similar concentrations of the drowning medium (Sasidharan and Resmi 2014). A detailed study of phytoplanktons and their relationship with characteristics of the water body can play a significant role in connecting a drowned dead body to a

Table 7 Seasonal variation in phytoplankton diversity indices in Braham Sarovar and Prithus pools

\begin{tabular}{lllll}
\hline Water Body & Season & Shannon diversity index & Evenesss & Species richness \\
\hline Braham sarovar & Summer & 3.32676 & 0.93 & 4.55 \\
& Autumn & 3.31251 & 0.89 & 3.96 \\
& Winter & 2.90562 & 0.86 & 3.87 \\
Spring & 3.11771 & 0.89 & 4.60 \\
Prithus pool & Summer & 3.139102 & 0.93 & 3.68 \\
& Autumn & 2.951855 & 0.90 & 3.42 \\
& Winter & 2.9244777 & 0.90 & 3.44 \\
& Spring & 3.1210465 & 0.90 & 3.86 \\
\hline
\end{tabular}


Table 8 Physico-chemical Parameters of Prithus Pool

\begin{tabular}{|c|c|c|c|c|c|c|c|c|c|c|}
\hline \multicolumn{11}{|c|}{ Prithus pool } \\
\hline $\begin{array}{l}\text { Season of } \\
\text { sampling }\end{array}$ & $\mathrm{pH}$ & $\begin{array}{l}\text { EC } \\
(\mu \mathrm{s} / \mathrm{cm})\end{array}$ & $\begin{array}{l}\text { TDS } \\
(\mathrm{mg} / \mathrm{l})\end{array}$ & $\begin{array}{l}\text { HARDNE } \\
\text { SS (mg/L) }\end{array}$ & $\begin{array}{l}\text { ALKALINITY } \\
(\mathrm{mg} / \mathrm{L})\end{array}$ & $\begin{array}{l}\text { SODIUM } \\
\text { ppm }\end{array}$ & $\begin{array}{l}\text { POTASIUM } \\
\text { ppm }\end{array}$ & $\begin{array}{l}\text { CHLORIDE } \\
(\mathrm{mg} / \mathrm{L})\end{array}$ & $\begin{array}{l}\text { CALCIUM } \\
(\mathrm{mg} / \mathrm{L})\end{array}$ & $\begin{array}{l}\text { WATER TEMPERTU } \\
\left.\text { RE }{ }^{(0} \mathrm{C}\right)\end{array}$ \\
\hline Summer & 7.7 & 254 & 500 & 340 & 180 & 20 & 3.4 & 122 & 120 & 35.2 \\
\hline Autumn & 7.1 & 227 & 474 & 250 & 177 & 18 & 4.2 & 91 & 104 & 32.4 \\
\hline Winter & 6.9 & 130 & 434 & 230 & 145 & 21.5 & 4.8 & 57 & 96 & 16.5 \\
\hline Spring & 7.2 & 198 & 587 & 310 & 189 & 28.6 & 2.8 & 94 & 76 & 22.1 \\
\hline Average & $7.2 \pm 0.34$ & $198 \pm 60$ & $498 \pm 64.7$ & $280.7 \pm 55.3$ & $172.7 \pm 19.1$ & $22 \pm 4.6$ & $3.8 \pm 0.8$ & $91.0 \pm 26$ & $99.0 \pm 18.2$ & $26.5 \pm 8.7$ \\
\hline
\end{tabular}

specific water body source particularly when the body is found outside or lying adjacent to the water body.

In the present the study, PCA method has been employed to 10 physico-chemical parameters for 20 dominant species of phytoplankton for Prithus pool. The PCA axis 1 and 2 explained 42.81 and $36.70 \%$ variation in phytoplankton and physico-chemical parameter. Crucigeniella quadrata, Crucigenia tetrapedia, Scenedesmus dimorphus, Scenedesmus quadricauda, Planktothrix mougeotti, and Melosira varians are positively co-related to $\mathrm{pH}$, hardness, alkalinity, chloride, electrical conductivity and temperature of water sample while Crucigenia crucifera is negatively co-related with all these factors. Dictyochloropsis reticulata, Tetrastrum punctatum, and Frustulia vulgaris are positively co-related to TDS (total dissolved solids) and sodium while Nitzschia palea is negatively co-related to TDS. Lepocinclis ovum and Nitzschia palea are positively correlated to potassium while Coelastrum microporum and Coelastrum astroideum are positively correlated to calcium (Fig. 5).

PCA for Braham Sarovar has been drawn by taking in to account 10 physico-chemical parameters and 14 dominant species of phytoplankton. The PCA axis 1 explained $50.14 \%$ and axis 2 explained 29.03\% variations in phytoplankton and physico-chemical parameters. Aulacoseira granulata, Tetraedron minimum, Gloeocapsa minimum, Nitzschia palecea, and Coelastrum microporum, is positively correlated to temperature whereas Microcystis aeruginosa and Synechococcus sp. are negatively correlated. Chroococcus dispersus and Aphanothceae sp. have been positively correlated with calcium and Ankistrodesmus fusiformis is positively correlated with chloride. Phacus longicauda, Phacus tortus, Lepocinclis fusiformis, and Synechococcus sp. are positively co-related with $\mathrm{pH}$, potassium, hardness and electrical conductivity whereas they all are negatively correlated with TDS and calcium. Similarly, Synechococcus sp. and Microcystis aeruginosa are positively co-related with $\mathrm{pH}$ and alkalinity (Fig. 6).

\section{Phytoplankton maps (P- maps) of Braham Sarovar and Prithus pools}

Among the total 138 species, 13 species were common in both the water bodies, therefore, these are categorized as common species and are significant in diagnosing the drowning death, but not significant in determining the exact site of drowning. Similarly, rarely occurring species in Braham Sarovar (25 species) and Prithus pools (20 species) are not forensically significant. The site-specific species in Braham Sarovar (4 species) and Prithus pools (4 species) are forensically significant in determining the exact/putative site of drowning. The P-maps with a list of common and site-specific phytoplanktons have been shown in Tables 4 and 5 . The P-map generated of phytoplankton species of two water bodies can help in determining not only cause of death, but also helps in linking the suspects to a crime scene.

\section{Conclusions}

In the present study, phytoplankton data have been generated from the season-wise analysis of two water bodies: Braham

Table 9 Physico-chemical Parameters of Braham Sarovar

\begin{tabular}{|c|c|c|c|c|c|c|c|c|c|c|}
\hline \multicolumn{11}{|c|}{ Braham Sarovar Lake } \\
\hline $\begin{array}{l}\text { Season of } \\
\text { sampling }\end{array}$ & $\mathrm{pH}$ & $\begin{array}{l}\mathrm{EC} \\
(\mu s / \mathrm{cm})\end{array}$ & $\begin{array}{l}\text { TDS } \\
(\mathrm{mg} / \mathrm{l})\end{array}$ & $\begin{array}{l}\text { HARDNE } \\
\text { SS (mg/L) }\end{array}$ & $\begin{array}{l}\text { ALKALINITY } \\
(\mathrm{mg} / \mathrm{L})\end{array}$ & $\begin{array}{l}\text { SODIUM } \\
\text { ppm }\end{array}$ & $\begin{array}{l}\text { POTASIUM } \\
\text { ppm }\end{array}$ & $\begin{array}{l}\text { CHLORIDE } \\
(\mathrm{mg} / \mathrm{L})\end{array}$ & $\begin{array}{l}\text { CALCIUM } \\
(\mathrm{mg} / \mathrm{L})\end{array}$ & $\begin{array}{l}\text { WATER TEMPERTU } \\
\text { RE }\left({ }^{\circ} \mathrm{C}\right)\end{array}$ \\
\hline Summer & 6.2 & 85 & 179 & 90 & 20 & 4.6 & 0.8 & 32 & 54.54 & 35.3 \\
\hline Autumn & 7.6 & 96 & 170 & 110 & 70 & 4.2 & 1.2 & 25 & 48.9 & 29.8 \\
\hline Winter & 7.2 & 98 & 155 & 89 & 76 & 4.8 & 0.8 & 28 & 44.2 & 17.5 \\
\hline Spring & 6.9 & 82 & 184 & 86 & 48 & 3.2 & 0.6 & 39 & 27.8 & 33.7 \\
\hline Average & $6.9 \pm 0.59$ & $90.25 \pm 7.9$ & $172 \pm 12.7$ & $93.7 \pm 10.09$ & $53.5 \pm 25.3$ & $4.2 \pm 0.7$ & $0.8 \pm 0.2$ & $31.0 \pm 6.0$ & $43.8 \pm 29$ & $29.0 \pm 8.0$ \\
\hline
\end{tabular}




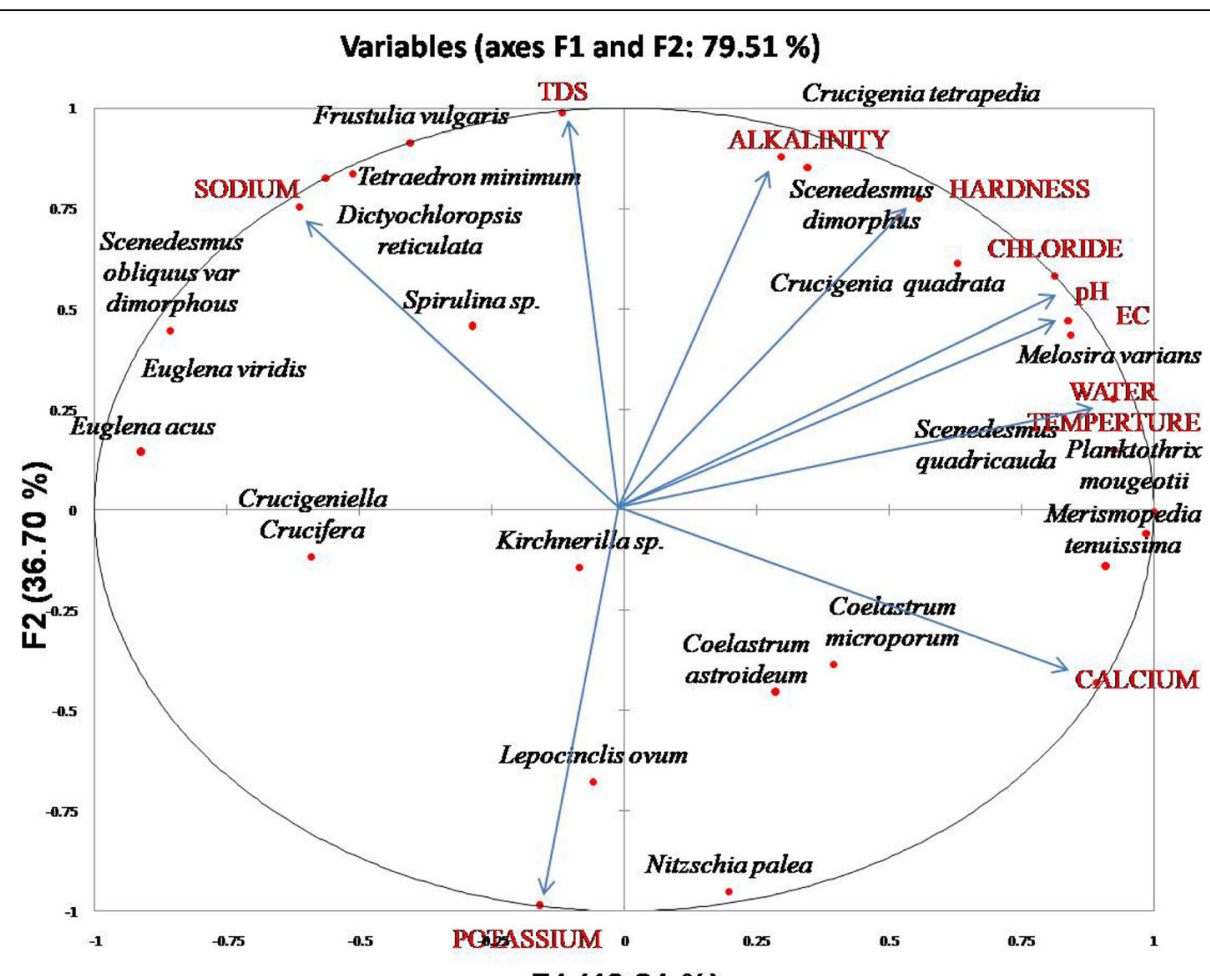

F1 (42.81\%)

Fig. 5 Principal Component Analysis of physico-chemical parameters and dominant species of Prithus Pool

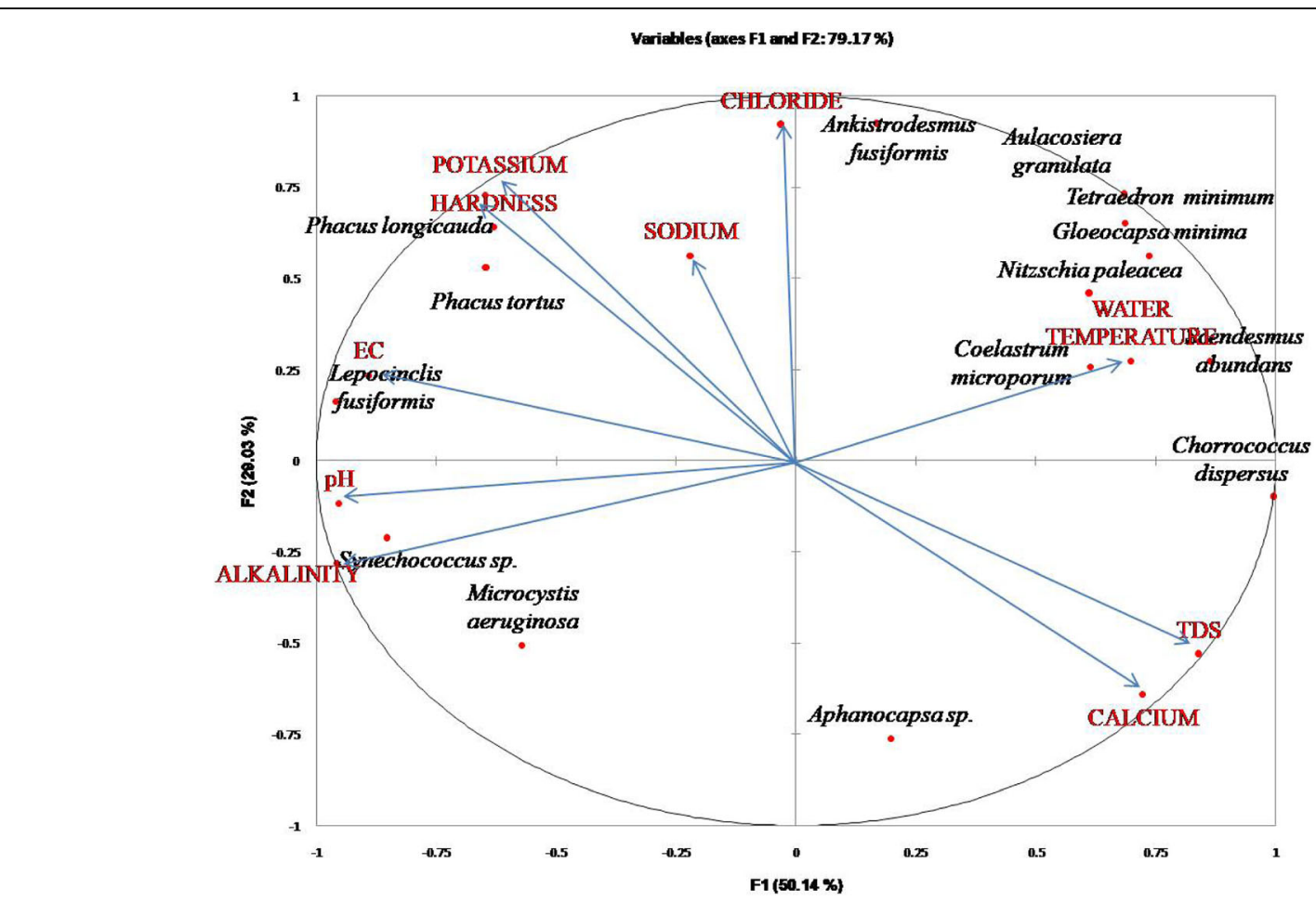

Fig. 6 Principal Component Analysis of physico-chemical parameters and dominant species of Braham Sarovar 
Sarovar and Prithus pools of the historically important cities (Kurukshetra and Pehowa) of Haryana State, for two years continuously. The data analysis differentiated phytoplankton into common, rare, and site-specific species in order to construct phytoplankton-map. The P-maps generated for the two water bodies of Haryana state, India, are expected to be useful to forensic experts and forensic medicine experts in solving drowning cases and unfolding mysteries related to the putative site of drowning, especially when diatoms are present in very less number during a particular season. In addition, the data has been successfully used to find the degree of correlation between different environmental parameters and phytoplanktons prevailing in a water body with the help of Principal Component Analysis method.

\section{Abbreviations \\ APHA: America Public Health Association; D: Species richness; EC: Electrical conductivity; H: Shannon and weaver diversity index; J: Evenness; N: Total number of individuals in the sample; $n$ : Total number of species in the sample; PCA: Principal component analysis; P-map: Phytoplankton map; S: Total number of species in the sample; TDS: Total dissolved solids}

\section{Acknowledgements}

Authors are thankful to U.G.C, New Delhi for providing U.G.C NET/JRF fellowship to one of authors, Deepali luthra to carry out this research.

\section{Funding}

U.G.C NET/JRF fellowship.

\section{Availability of data and materials}

The datasets generated during and/or analyzed during the current study are available from the corresponding authors on reasonable request.

\section{Authors' contributions}

Study conception and design: MKT, JSK, DL. Acquisition of data: DL. Analysis and interpretation of data: DL, MKT, JSK. Drafting of manuscript: DL. Critical revision: MKT, JSK, DL. All authors read and approved the final manuscript.

\section{Ethics approval and consent to participate}

Ethical approval and consent to participate were not required.

\section{Competing interests}

The authors declare that they have no competing interest.

\section{Publisher's Note}

Springer Nature remains neutral with regard to jurisdictional claims in published maps and institutional affiliations.

\section{Author details}

'Department of Forensic Science, Punjabi University, Patiala, India.

${ }^{2}$ Department of Botany, Punjabi University, Patiala, India.

Received: 18 November 2017 Accepted: 15 May 2018

Published online: 29 May 2018

\section{References}

APHA (American Public Health Association), American Water Works Associations (AWWA) and Water Environment Federation (WEF) (2005) Standard methods for the examination of water and wastewater. APHA (American Public Health Association), American Water Works Associations (AWWA) and Water Environment Federation (WEF), Washington DC

Auer A, Möttönen M (1988) Diatoms and drowning. Zeitschrift für Rechtsmedizin 101:87-98

Baba Al, Pandit AK (2014) Species composition, diversity and population Dyanamics of phytoplankton at Saderkot in Wular Lake, Kashmir. J Eco Ecogr 4:142-150
Canini ND, Metillo EB, Azanza RV (2013) Monsoon-influenced phytoplankton community structure in a Philippine mangrove estuary. Trop Ecol 54:331-343

Chardez D, Lambert J (1985) Protozoaires ciliés et thanatologie. Forensic Sci Int 28:83-101

Cumming BF, Smol JP (1993) Development of diatom-based salinity models for paleoclimatic research from lakes in British Coloumbia (Canada). Twelfth International Diatom Symposius. Hydrobiologia. Springer, Dordrecht, pp 17996, vol. 269

Desikachary TV (1959) Cyanophyta. Indian Council of Agricultural Research, New Delhi

Díaz-Palma P, Alucema A, Hayashida G, Maidana N (2009) Development and standardization of a microalgae test for determining deaths by drowning. Forensic Sci Int 184:37-41

Figueredo CC, Giani A (2009) Phytoplankton community in the tropical lake of Lagoa Santa (Brazil): conditions favoring a persistent bloom of Cylindersospermosis raciborskii. Limnologica 39:264-272

Hall DW (1997) Forensic botany. Forensic Taphonomy: the postmortem fate of human remains. CRC Press, Inc., Boca Raton

Khuantrairong T Traichaiyaporn S (2008) Diversity and seasonal succession of the phytoplankton community in Doi Tao lake, Chiang Mai Province, northern Thailand. Tropical. Nat Hist 8:143-156

Kim YS (2011) Research for seasonal plankton distribution of in-land water in Gwang-ju Area.Korean. J Legal Med 35:16-21

Komárek J, Fott B, Huber-Pestalozzi G (1983) Das Phytoplankton des Süßwassers. Systematik und Biologie-Teil 7, 1. Hälfte.

Ludes B, Coste M, North N, Doray S, Tracqui A, Kintz P (1999) Diatom analysis in victim's tissues as an indicator of the site of drowning. Int I Legal Med 112 163-166

Lunetta P, Miettinen A, Spilling K, Sajantila A (2013) False-positive diatom test: a real challenge? A post-mortem study using standardized protocols. Legal Med 15:229-234

Lunette P, Modell JH (2005) Macroscopical microscopical and laboratory findings in drowning victims. In: Tsokos M. (eds) Forensic Pathology Reviews, vol. 3. Humana Press, Totowa NJ

Menhinick EF (1964) A comparison of some species-individuals diversity indices applied to samples of field insects. Ecology 45:859-861

Nowrouzi S, Valavi H (2011) Effects of environmental factors on phytoplankton abundance and diversity in Kaftar Lake. J Fish Aquat Sci 6:130-140

Otto $H$ (1961) On the demonstration of diatoms in human lung dust. Frankfurter Zeitschrift für Pathologie 71:176-181

Panigrahi S, Patra A (2013) Studies on seasonal variations in phytoplankton diversity of river Mahanadi, Cuttack city, Odisha, India. Indian I Sci Res 4:211-217

Philipose M T (1967) Chlorococcales. Indian Council of Agricultural Research, New Delhi

Pielou E (1975) Indices of diversity and evenness. Ecological Diversity. Wiley, New York

Pollanen M (1997) The diagnostic value of the diatom test for drowning, II. Validity: analysis of diatoms in bone marrow and drowning medium. J Forensic Sci 42:286-290

Prescott GW (1962) Algae of the western Great Lakes area.WC Brown Company Dubuque.

Raibole M, Singh YP (2011) Impact of physico-chemical parameters on microbial diversity:seasonal study. Curr World Environ 6:71-76

Sasidharan A, Resmi S (2014) Forensic diatomology. Health Sciences 3:1-16

Shannon CE (2001) A mathematical theory of communication. ACM SIGMOBILE Mobile Comput Commun Rev 5:3-55

Shinde S, Pathan T, Sonawane D (2012) Seasonal variations and biodiversity of phytoplankton in Harsool-Savangi dam, Aurangabad, India. J Environ Biol 33: 643-647

Singh M, Lodha P, Singh GP (2010) Seasonal diatom variations with reference to physico-chemical properties of water of Mansagar Lake of Jaipur, Rajasthan. Res J Agric Sci 1:451-457

Singh R, Singh R, Kumar S, Thakar M (2006a) Forensic analysis of diatoms-a review. Anil Aggrawal's Internet J Forensic Med Toxicol 7

Singh R, Singh R, Singh R, Thakar M (2006) Diatomological studies from three water bodies of Jaipur. Indian Internet Journal of Forensic Medicine \& Toxicology 4:1-11

Singh R, Singh R, Thakar MK (2005) Drowning associated diatoms. Indian Intern J Forens Med Toxicol 3

Singh SR, Swarup K (1980) Studies on the primary production of phytoplankton in Suraha lake (Ballia, India). Int Rev Hydrobiol 65:709-717 
Siver PA, Lord WD, McCarthy DJ (1994) Forensic limnology: the use of freshwater algal community ecology to link suspects to an aquatic crime scene in southern New England. J Forens Sci 39:847-853

Spitz W, Schmidt H, Fett W (1965) Studies on air filtration strips from different regions of the federal republic for their diatom content. A contribution to the value of diatoms in the diagnosis of death by drowning. Deutsche Zeitschrift für die gesamte gerichtliche Medizin 56:116

Stanier R, Kunisawa R, Mandel M, Cohen-Bazire G (1971) Purification and properties of unicellular blue-green algae (order Chroococcales). Bacteriol Rev 35:171

Sushanth V, Rajashekhar M (2012) Seasonal variation in diatoms in response to physico-chemical characteristics of coastal waters of Uttara Kannada district, west coast of India. International. J Environ Sci 2:1543-1552

Thakar MK, Luthra D, Singh R (2011) A fluorescent survey of diatom distribution patterns in some small water bodies (lakes and Sarovars). J Punjab Acad Forens Med Toxicol 11:81-86

Thakar MK, Singh R (2009) Diatoms. Wiley Encyclopedia of Forensic Science, United Kingdom

Thakar MK, Singh R (2010) Diatomological mapping ofss water bodies for the diagnosis of drowning cases. J Forensic Legal Med 17:18-25

Tiwari A, Chauhan SVS (2006) Seasonal phytoplanktonic diversity of Kitham lake, Agra. J Environ Biol 27:35-38

Venkateswarlu V (1969) An ecological study of the algae of the river Moosi, Hyderabad (India) with special reference to water pollution. Hydrobiologia 34:533-560

Wehr JD, Sheath RG, Kociolek JP (2015) Freshwater Algae of North America: Ecology and Classification. Academic Press, New York

Yen LY, Jayaprakash P (2007) Prevalence of diatom frustules in non-vegetarian foodstuffs and its implications in interpreting identification of diatom frustules in drowning cases. Forensic Sci Int 170:1-7

Yoshimura S, Yoshida M, Okii Y, Tokiyasu T, Watabiki T, Akane A (1995) Detection of green algae (Chlorophyceae) for the diagnosis of drowning. Int I Legal Med 108:39-42

\section{Submit your manuscript to a SpringerOpen ${ }^{\circ}$ journal and benefit from:}

- Convenient online submission

- Rigorous peer review

- Open access: articles freely available online

- High visibility within the field

- Retaining the copyright to your article

Submit your next manuscript at $\gg$ springeropen.com 